\title{
Education of organic chemistry at the grammar school - problem parts of subject
}

\author{
Eliška Tvarohová ${ }^{1 a}$, and Simona Hybelbauerová ${ }^{1}$ \\ ${ }^{1}$ Charles University in Prague, Faculty of Science, Department of Teaching and Didactics of \\ Chemistry, Prague, Czech Republic
}

\begin{abstract}
In teaching of chemistry, every teacher can enumerate some topics of the chemistry curriculum, which are hard to understand or to memorize for grammar school students. These topics were defined as a problematic parts of subject. There was a qualitative educational research conducted with teachers of chemistry at grammar schools. The goal of the research was not limited to determinate the difficult parts of curriculum in organic chemistry but also included methods of the teaching. Finally the research also encompassed the reason behind the root causes misunderstanding of organic chemistry topics. Based on the results of this research there were new learning materials designed. They show the problematic topics of organic chemistry in different ways using other teaching methods. These materials will be consulted with teachers and theory will be proved in chemistry lesson at grammar school.
\end{abstract}

Keywords: chemistry curriculum; problematic parts of curriculum; learning materials in organic chemistry; educational research, grammar school

\section{Introduction}

Chemistry education at the grammar school level is defined in educational objectives which are laid down by Framework Education Programme for grammar schools [1] and further detailed by the grammar school. Experiences of teachers and their long-standing practice show the educational areas which are repeatedly hard to understand for students. This could have a bad impact to the achievement of educational objectives. There was a research conducted to discover the problem parts and their causes focused on organic chemistry at grammar school. It is the first goal of the project. Based on the results of the research there were the new learning materials developed, which explain the problem areas and their educational content another way and they can probably more easily achieve the educational objectives. This was considered as the second main goal of the project.

\footnotetext{
${ }^{a}$ Corresponding author: eliska.tvarohova@gmail.com
} 


\section{Methods}

All goals of the study were reached by several methods, which depend on each other. The results of one were used as an input of the next.

The qualitative educational research was made in 2015. There were 15 teachers with an average length of their practice of 17 years, who got involved in the research. A questionnaire and controlled interview were chosen as tools for the research [2]. Teachers could answered the questions by themselves or selected from various possibilities of answers. These results were the most important step in the research, because they presented the problem parts of organic chemistry an their causes at grammar school and also their supposed causes. Teachers have expressed the interest of various materials and provided valuable advices and ideas.

After finding out the problem areas there was made a short comparative analysis of these parts in the six most frequently used chemical textbooks [3]. The analysis was based on defined criteria, which were evaluated by point scale from $1=$ minimum to $3=$ maximum. Analysis of textbooks monitored the content, range, intelligibility, text structure, difficulty of topic, selected reactions, their mechanisms, examples of compounds, explanation of new words, pictures, graphs, motivational text, questions and tasks for students. All these informations were useful for design of new learning materials and worksheets [4].

\section{Findings}

The qualitative educational research results show four the most problematic topics in organic chemistry at the grammar school. The first topic is inductive and mesomeric effects. Teachers said, student don't comprehend the main substance of effects. The second topic are reaction mechanisms. Teachers are missing comprehensive and systematic materials which simplify and better explain the topic to students. The third topic is organic nitrogen compounds. Students supposedly don't understand different properties of the compounds, nomenclature and also don't take interest in this topic. The fourth problematic part are heterocyclic compounds. This topic is probably too abstract and difficult which caused demotivation to study.

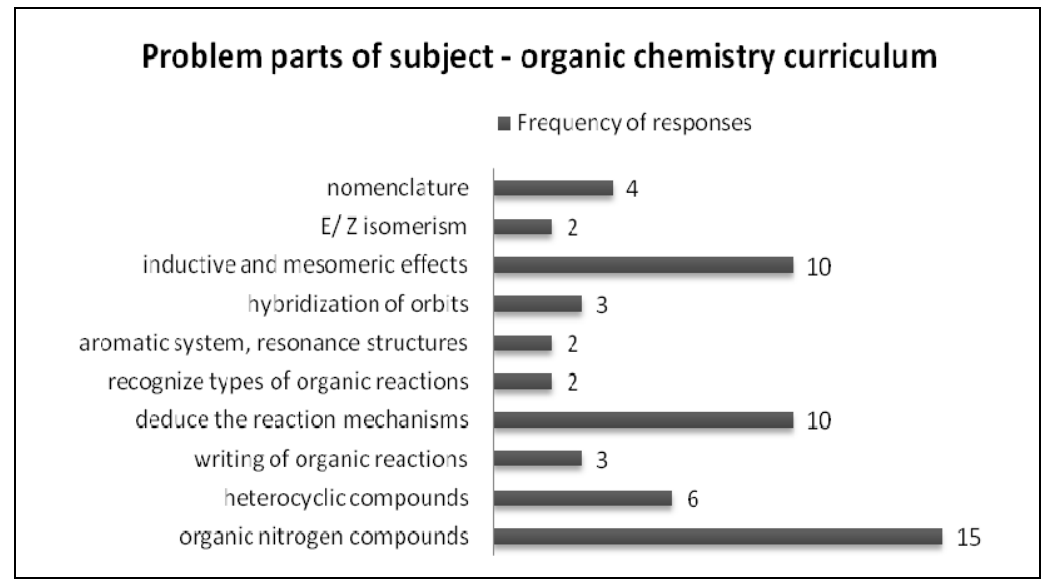

Graph 1. Problem parts of subject - organic chemistry curriculum

Teaching methods of these topics are usually lecture method, demonstration of a chemical experiment and continuesly repeating and explain of problem parts of curriculum. 


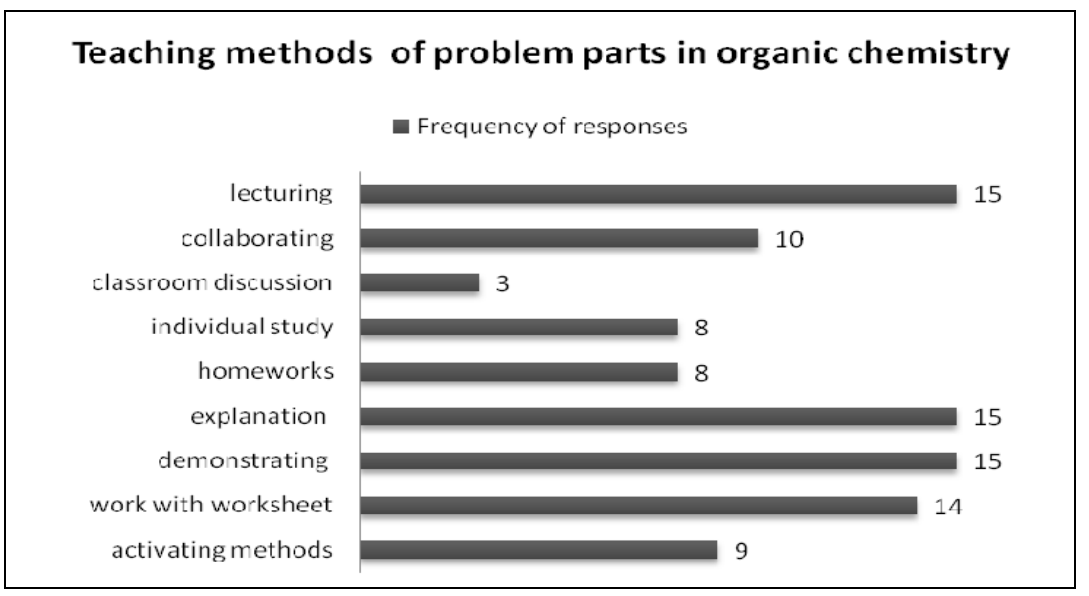

Graph 2. Teaching methods of problem parts in organic chemistry

Teachers also admitted they almost don't use the books so they would appreciate any other materials for teaching eg. worksheets, examples or interesting synthesis or things from daily life.

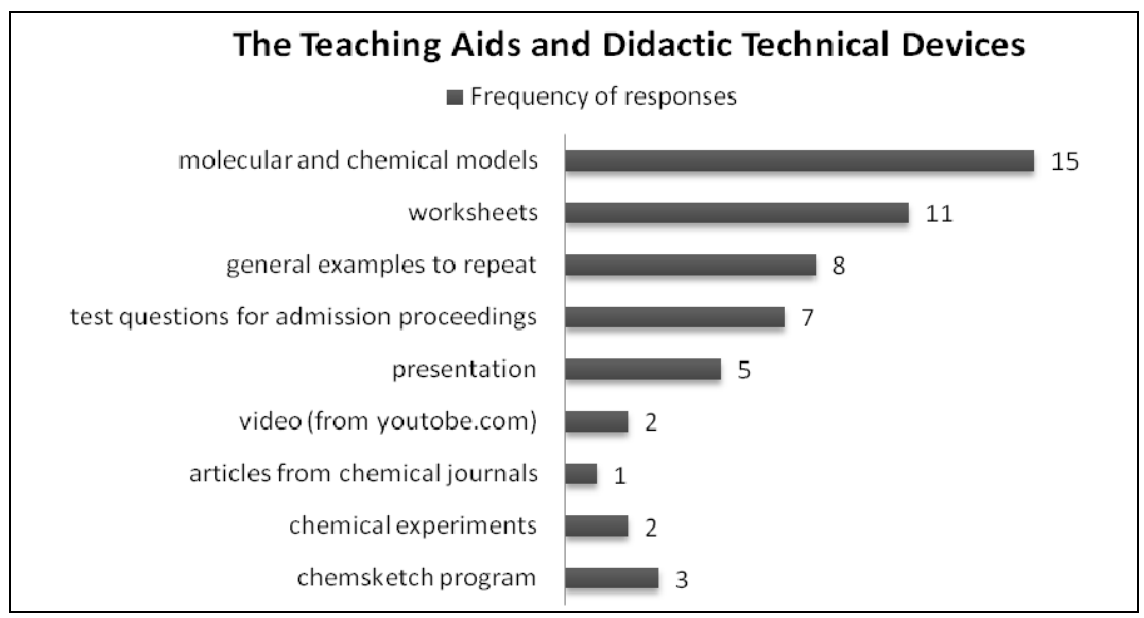

Graph 3. Teaching aids and didactic technical devices

\section{Discussion and conclusion}

One of the goal of the project was to design new learning materials [5], which can improve the teaching and could be helpful to teachers and their students as well. We tried to use other teaching methods and didactic technical devices. New learning materials explain the problem areas and their educational content another way and teachers with students can probably more easily achieve the educational objectives.

The topic inductive and mesomeric effects is presented as learning tasks for group lesson. All tasks should expand chemical thinking and stimulate thinking about the influence of the substituent on the whole molecule. The main aim of this material is steer students towards logical thinking, deduce from the properties of effects and explain that to the others in the group. They are responsible for the schoolwork and they can choose the way, how to explain that. The role of the teacher is just to be a kind of support for students 
in the group. Teacher is not the only one, who explains everything. There was designed the methodological guidelines for teachers, which contain the goals of the group lesson, realization part and the possibility of evaluation including some feedback questions.

After analysis of chemical textbooks and from the results of the research, there are seven the most teaching mechanisms of organic reactions. All of them were depicted to the powerpoint presentation. Firstly the reaction, next slide is the mechanism of the reaction. Below mechanism there are informations about the single steps and their causes. The presentation is including motivation tasks and interesting synthes. This material could be useful for teachers and students as well, considering that it is comprehensive overview of selected reaction mechanisms.

\section{Mechanism of elimination E1}
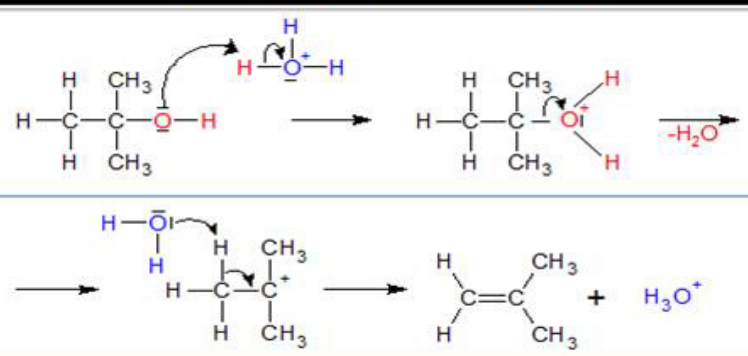

- The lone pairs on the oxygen make it a Lewis base.Cleavage of the C-O bond allows the loss of a neutral $\mathrm{H}_{2} \mathrm{O}$, to give a carbocation intermediate. Deprotonation by $\mathrm{H}_{2} \mathrm{O}$ from a $\mathrm{C}$ atom adjacent to the carbocation center leads to the creation of the $\mathrm{C}=\mathrm{C}$.

- E1 typically takes place with tertiary alkyl halides and alcohols.

Fig. 1. Reaction mechanism of elimination (E1)

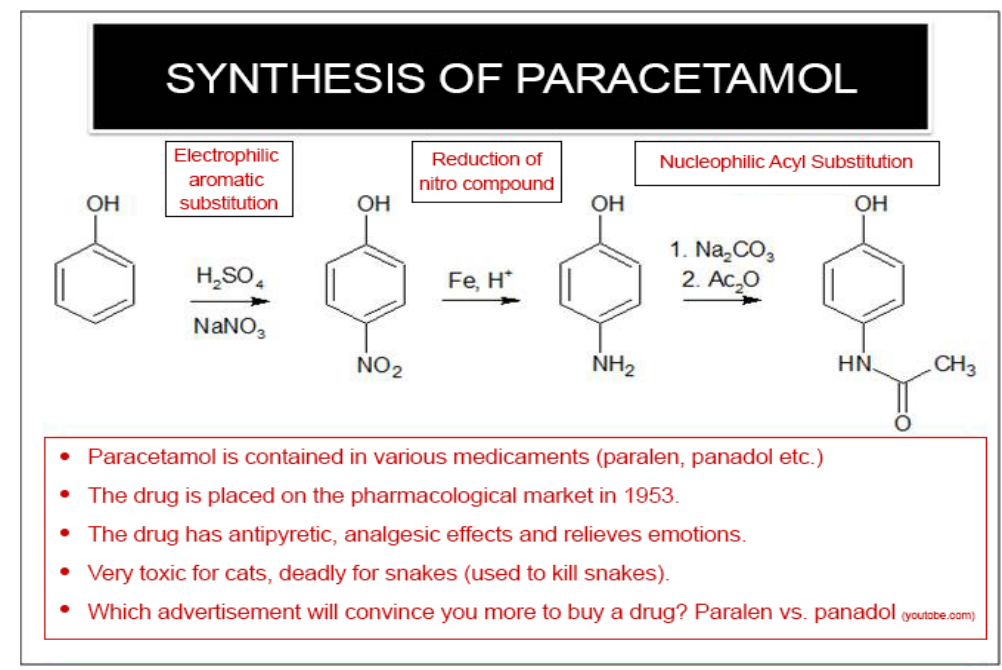

Fig. 2. Interesting synthesis of paracetamol

Different properties of the nitrogen compounds and nomenclature are explained by the worksheet. Students are working with incentive text, adds new information down to the 
teacher's interpretation and fulfil learning tasks, which are based on newly acquired knowledge. The worksheet is rich in compelling information and curious tasks from daily life. It should motivate the students and make the topic more interesting. The worksheet was created for students and also for teachers including solution of all tasks and questions.

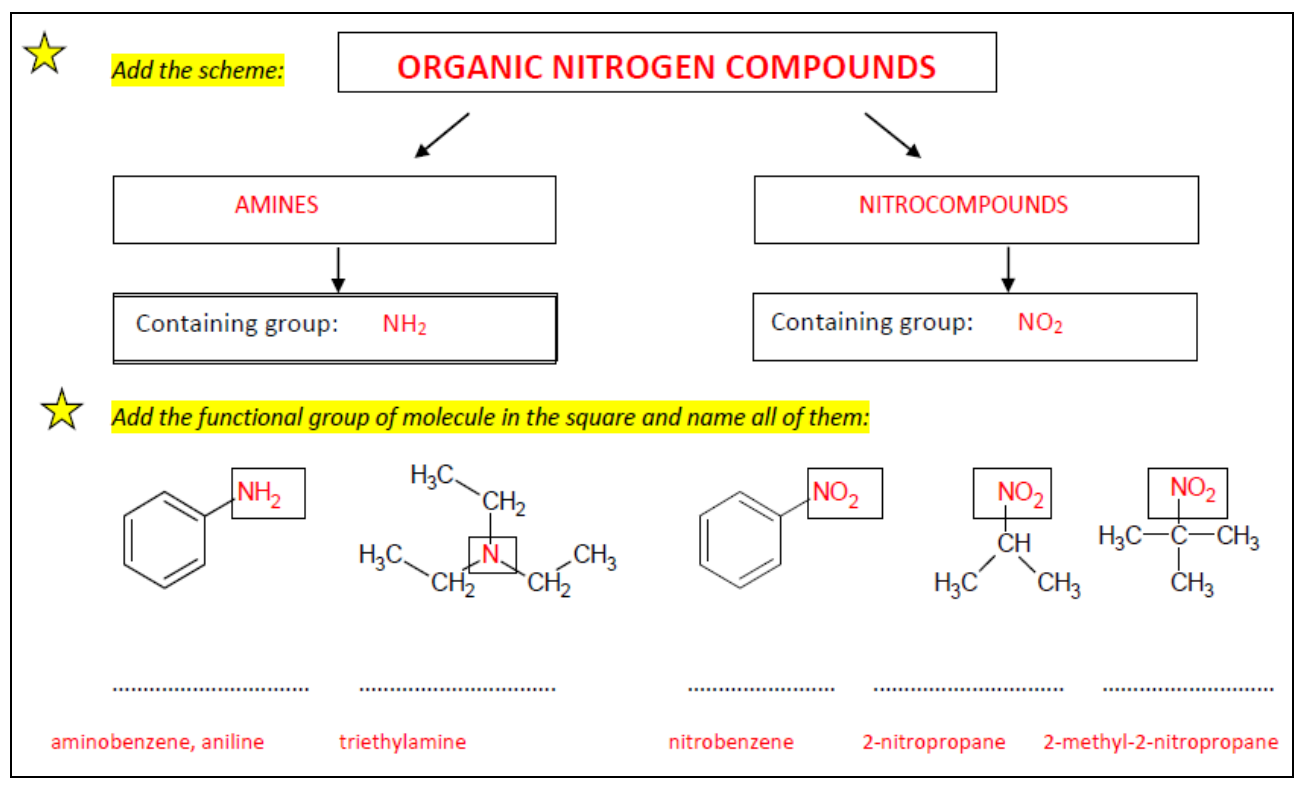

Fig. 3. Part from worksheet - Nitrogen compounds

Heterocyclic compounds are presented by project method of teaching with focus on motivation and interesting compounds from daily life of students. The intention of the project is to give students insight into the topic by themselves. There were chosen some compelling topic e.g. vitamins, medicine, drugs, hormones. The project method is demanding for teachers and organization of the lesson. Therefore there was designed the methodological guidelines for teachers, which could help them to organize the time and student's work.

The research found out the problem parts in organic chemistry curriculum at the grammar school, their causes and teaching methods of these topics. Established results were used as starting point for new designed learning materials. All materials were discussed with teachers and will be verify at grammar school.

During the educational research teachers have expressed the interest of accomplishment in the same research across whole chemical curriculum at the grammar school. The extended research is taking place and should introduce an overview to the problem parts of curriculum in chemistry. The output of the research is going to be an overview of problematic parts of chemistry curriculum and the set of learning materials which will ease the lectures and students understanding.

\section{References}

1. MŠMT. Rámcový vzdělávací program pro gymnázia: RVP G. Praha: Národní ústav pro vzdělávání, 2007. ISBN 978-80-87000-11-3

2. Skalková, J. a kol. Úvod do metodologie a metod pedagogického výzkumu. Praha: SPN, 
1983

3. Huvarová, M. Nejpoužívanějši středoškolské učebnice chemie na gymnáziích [online]. Olomouc, 2010, [cit. 2015-7-12]. Bakalářská práce. Katedra anorganické chemie, Př́rodovědecká fakulta, Univerzita Palackého v Olomouci. Vedoucí práce doc. RNDr. Marta Klečková, CSc.

4. Mrázová, L. Tvorba pracovních listi̊: metodický materiál [online]. Brno: Metodické centrum muzejní pedagogiky, 2012, [cit.2016-4-12]. Dostupné z: HTTP:/MCMP.OMEGADESIGN.CZ/FILEADMIN/USER_UPLOAD/VZDELAVANI/METODICKE_TE XTY/10_PRACOVNI_LISTY_S_ISBN_1._11..PDF. ISBN 978-80-7028-403-2.

5. Lepil, $\overline{\mathrm{O}}$. Teorie a praxe tvorby výukových materiáli [online]. Olomouc: Univerzita Palackého v Olomouci, 2010, [cit.2016-4-12]. Dostupné z: http://zvyp.upol.cz/publikace/lepil.pdf. ISBN 978-80-244-2489-7 